\title{
APPLYING OF MULTI-SECTION PRESSED PILES IN THE COMPLEX WITH A FOUNDATION PLATE DURING THE CONSTRUCTION OF THE «TAURUS» HOTEL
}

\author{
${ }^{1}$ Kunanets Y.M., postgraduate student, \\ kunanets.yura@gmail.com, ORCID: 0000-0003-3171-5394 \\ ${ }^{1}$ Demchyna B., Doctor of Engineering, Professor, \\ ${ }^{1}$ National University «Lviv Polytechnic» \\ bogdan195809@gmail.com, ORCID:0000-0002-3498-1519 \\ 12 st. S. Bandera, Lviv, 79013, Ukraine
}

\begin{abstract}
Engineers need to solve many complex problems during reconstruction in a dense urban development. First of all, it is associated with the risk of adversely affecting the surrounding buildings and the need for additional measures to prevent it. In addition, limited construction conditions restrict the use of traditional technologies, machines and mechanisms. Designing the right and reliable foundation in each case requires an individual approach. This approach should be based on a comprehensive study of engineering and geological conditions, a detailed survey of the structures and taking into account their actual technical condition.

The article presents the developed method of execution of the pile foundation for a new multistory building using pressed multi-section pipe concrete micropiles. According to this technique, all work was performed by small-sized equipment without the use of dynamic loads. The design of the grillage plate was also developed, with special openings through which the multi-section piles were later pressed. The idea of making the first plate-grill was to take the weight of the reactive force from the pressurizing installation, which was attached to the reinforcement releases from the plate. Piles were joined to the base plate by welding to the mortgage parts, after pressing. Further, the space between the pile and the mortgage was filled with concrete.

A series of tests were carried out to check the load-bearing capacity of piles and their sedimentation during the design load. The static indentation was carried out by means of a power stand which was attached to the reinforcing anchor rods, which were previously concreted into a monolithic grill. The efficiency and reliability of the implemented solutions are analyzed. The developed method of execution of foundations for new construction with the use of multi-section pressed piles allowed to cope with the set tasks without additional financial costs.
\end{abstract}

Key words: foundation, multi-section piles, pressing.

Introduction. The current trend of urbanization of cities, creates a great need for construction of new buildings. In the cities there is a significant compaction of buildings and development of problematic land areas, construction of which was previously considered unprofitable due to the significant cost of additional engineering measures [1]. Very often construction is carried out in such difficult conditions that makes it impossible to use large construction equipment.

One such case was the construction of the «TAURUS» hotel on Knyaza Sviatoslava Square 9, in Lviv (Fig. 1).

Geological conditions required the use of a pile foundation, without creating a dynamic impact on neighboring structures. A good solution is to use micropiles, which are installed by methods that cause minimal disturbance to adjacent structures, soil, and the environment [2]. Additional restrictions were created by the presence of water-saturated layers of sand and peat in the soil thickness, so there was a choice between borehole injection and pressed piles. Construction equipment that performs such piles is usually large and heavy, which makes it impossible to use in areas where there are many communications and networks. Therefore, there was a need to develop a foundation that can be performed in such difficult conditions.

Bulletin of Odessa State Academy of Civil Engineering and Architecture, 2020, no. 79, page 145-151 


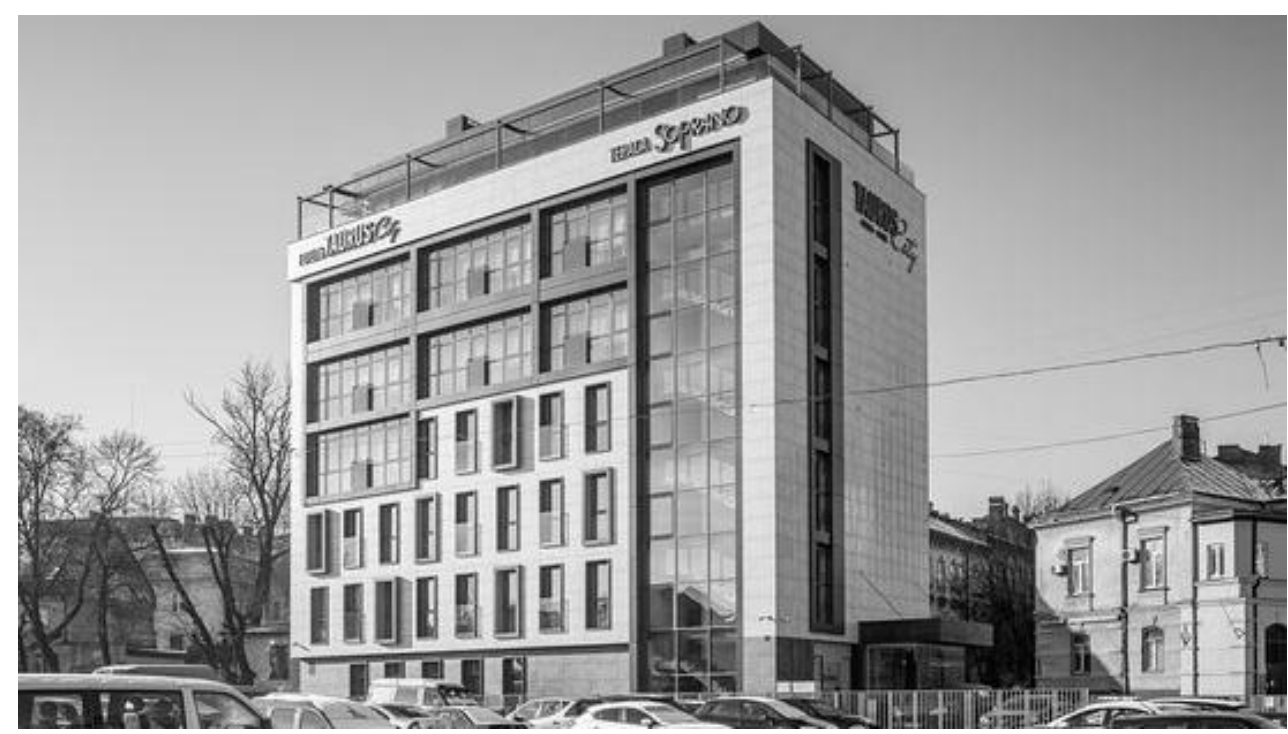

Fig. 1. «TAURUS» hotel

Analysis of recent research. The works of Lebeda O.F., Boyko I.P., Kornienko M.V., Movchan V.O., Prystupchuk V.V. are devoted to the study of the work of multi-section pressed micropiles of small diameter [3-4]. A significant contribution to the study of the load-bearing capacity of pipe-concrete piles is also the work of Morklyanyk B.V. "Strengthening the foundations of existing buildings on weak soils by pressing piles» [5], in which the rational design of the pile tip was developed and investigated, the value of the maximum pressing force was established, and it was found that the bearing capacity of pressed piles on the ground increases with the time of their rest, namely after 5 years up to $17 \%$.

Setting objectives. First of all, to develop a design and methods of execution of foundations for a 7-storey building. All work must be performed with small equipment without the use of dynamic loads. Three piles with static load were tested.

Research methodology. The main purpose of the tests was to check the bearing capacity of piles and their sedimentation during the design load of $250 \mathrm{kN}$.

The static indentation was carried out by means of a power stand, which was attached to the reinforcing anchor rods Ø25, which were previously concreted into a monolithic grill (Fig. 2).

The pile was loaded in separate stages with a centrally applied load from the hydraulic jack. The value of the degree of load was taken as $30 \mathrm{kN}$ in accordance with the requirements [6], which corresponded to $1 / 10$ of the magnitude of the maximum load $300 \mathrm{kN}$, predicted by the research program. At each stage, the load was maintained until the conditional stabilization of subsidence, which in accordance with the requirements of [6] p. 8.2.3 for these soil conditions was $0.1 \mathrm{~mm}$ for the last 60 minutes of observations. The subsidence of the micropile was measured by two deflectors of the Aistov system (DA-1, DA-2) located at two diametrically opposite points of section of the pile at its upper end.

Research results. Given the above conditions, it was decided to use pressed multi-section piles [4]. Pile - round section of casing $\varnothing 159 \times 4 \mathrm{~mm}$; reinforced with a spatial frame of longitudinal reinforcement 3Ø12A400C, and transverse Ø6A240C with a step $200 \mathrm{~mm}$; concrete class B20. The pile was made by pressing sections of length 1.2-1.8 $\mathrm{m}$, which were connected by welding. The average length of the piles was $10 \mathrm{M}$. The basis of the piles was the soil of EGE-6. Estimated load on the pile, according to the project $250 \mathrm{KN}$. Indentation effort $250 \times 1.4=350 \mathrm{KN}$. Thus, the pressing unit is small and has a low weight (up to $2 \mathrm{kN}$ ), it was decided to make at first a monolithic reinforced concrete slab, and use it to perceive the reactive force from the pressing of piles (Fig. 3, 4). 


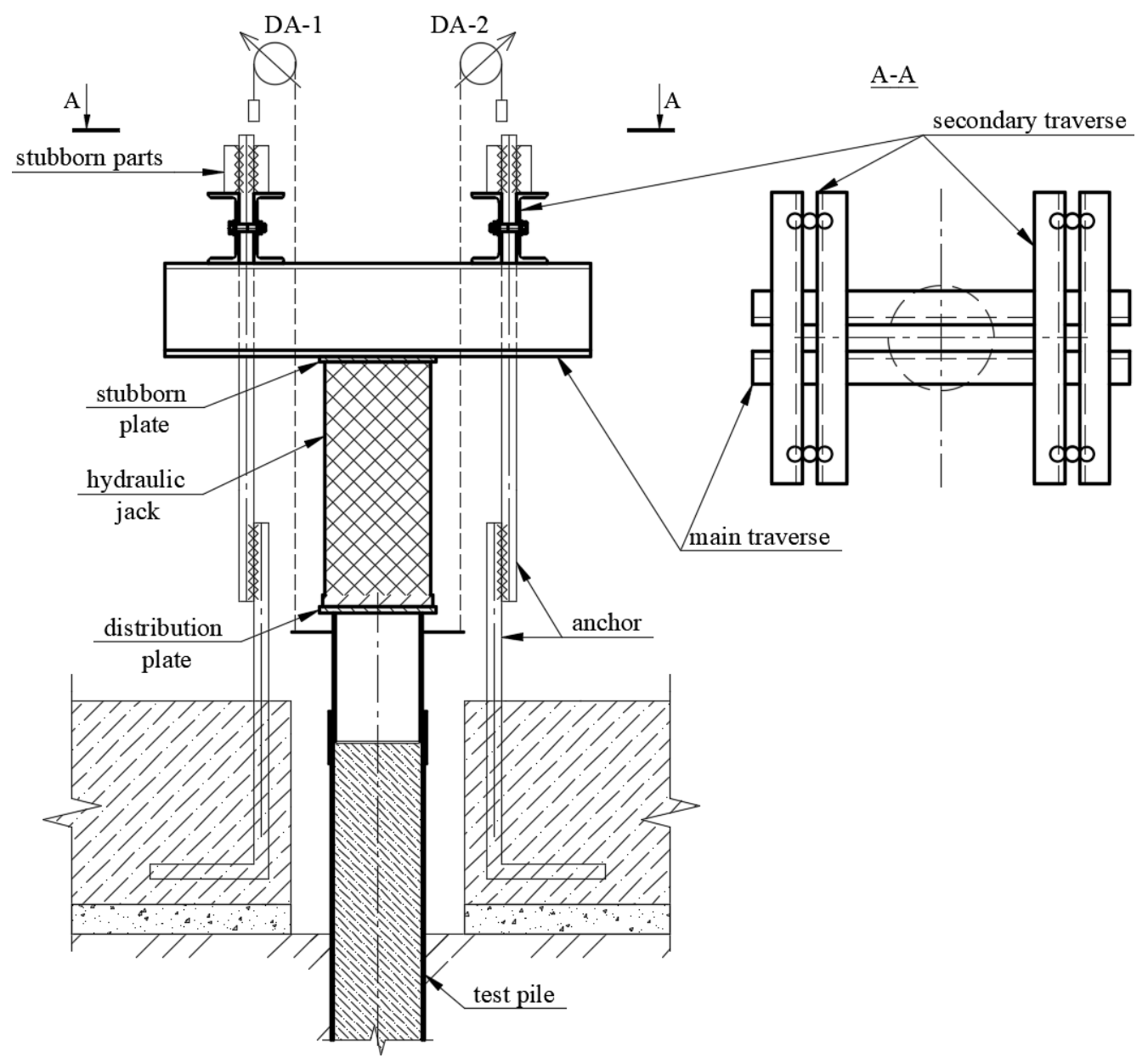

Fig. 2. Test scheme of a pipe-concrete pile

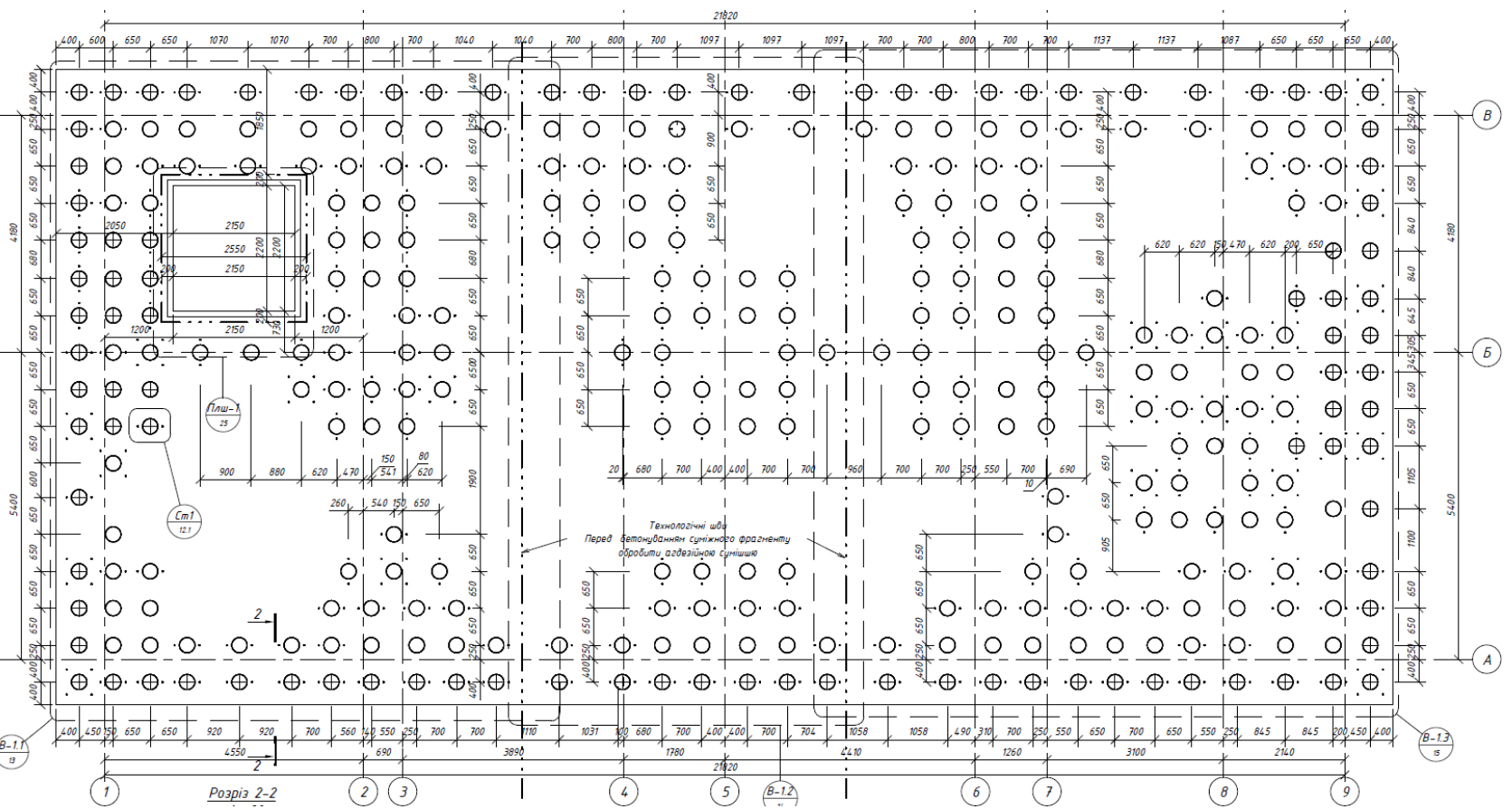

Fig. 3. Formwork scheme of the foundation slab 


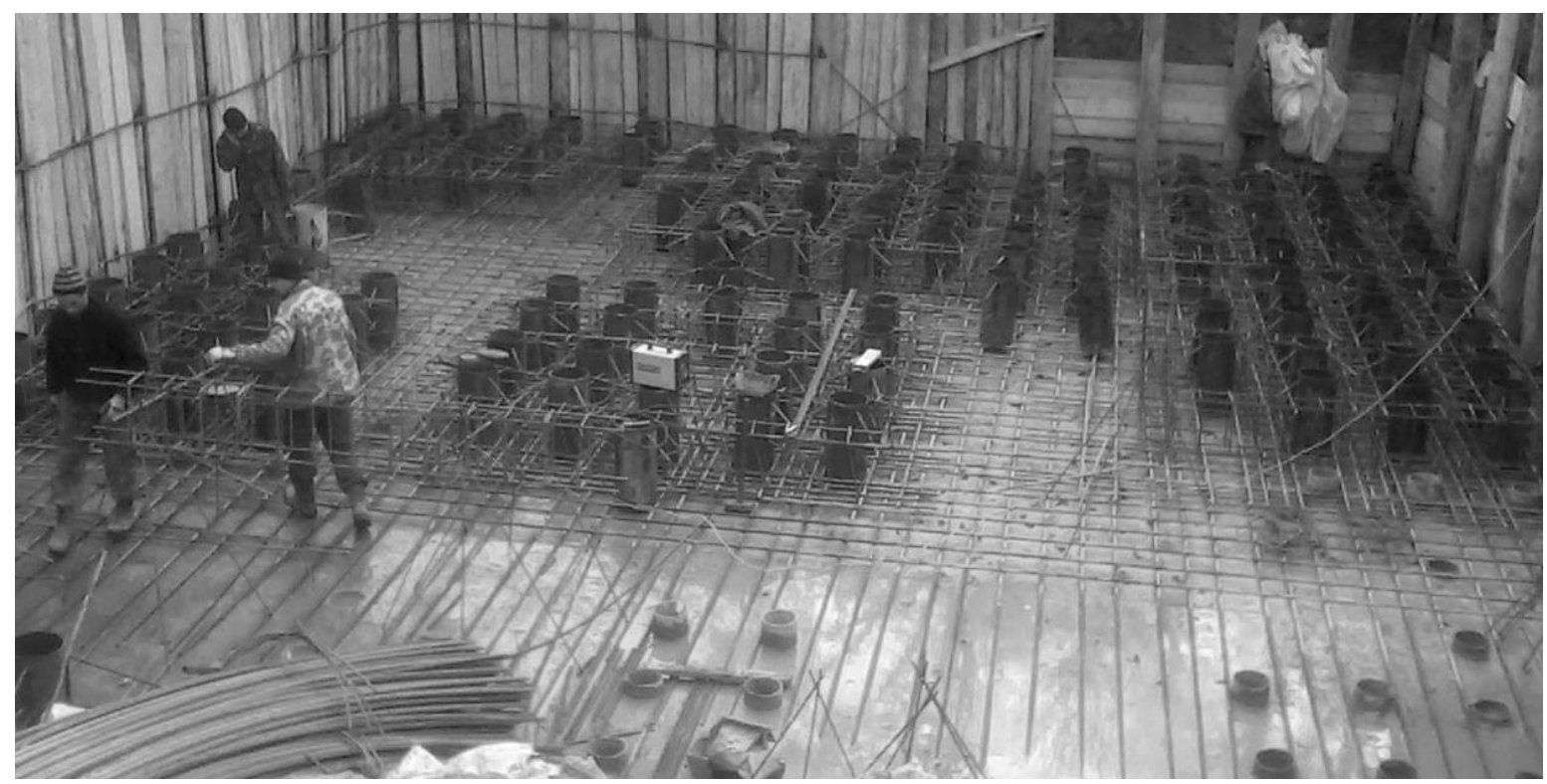

Fig. 4. The process of reinforcement of the foundation slab and installation of mortgage parts

During the reinforcement of the foundation slab, which in fact acted as a grille, special mortgage parts made of steel pipe $\varnothing 273 \mathrm{~mm}$ were mounted. Each pipe was anchored in a plate by means of welded bends of armature. Through these openings after a set of concrete of $70 \%$ of durability micropiles were pressed (Fig. 5).

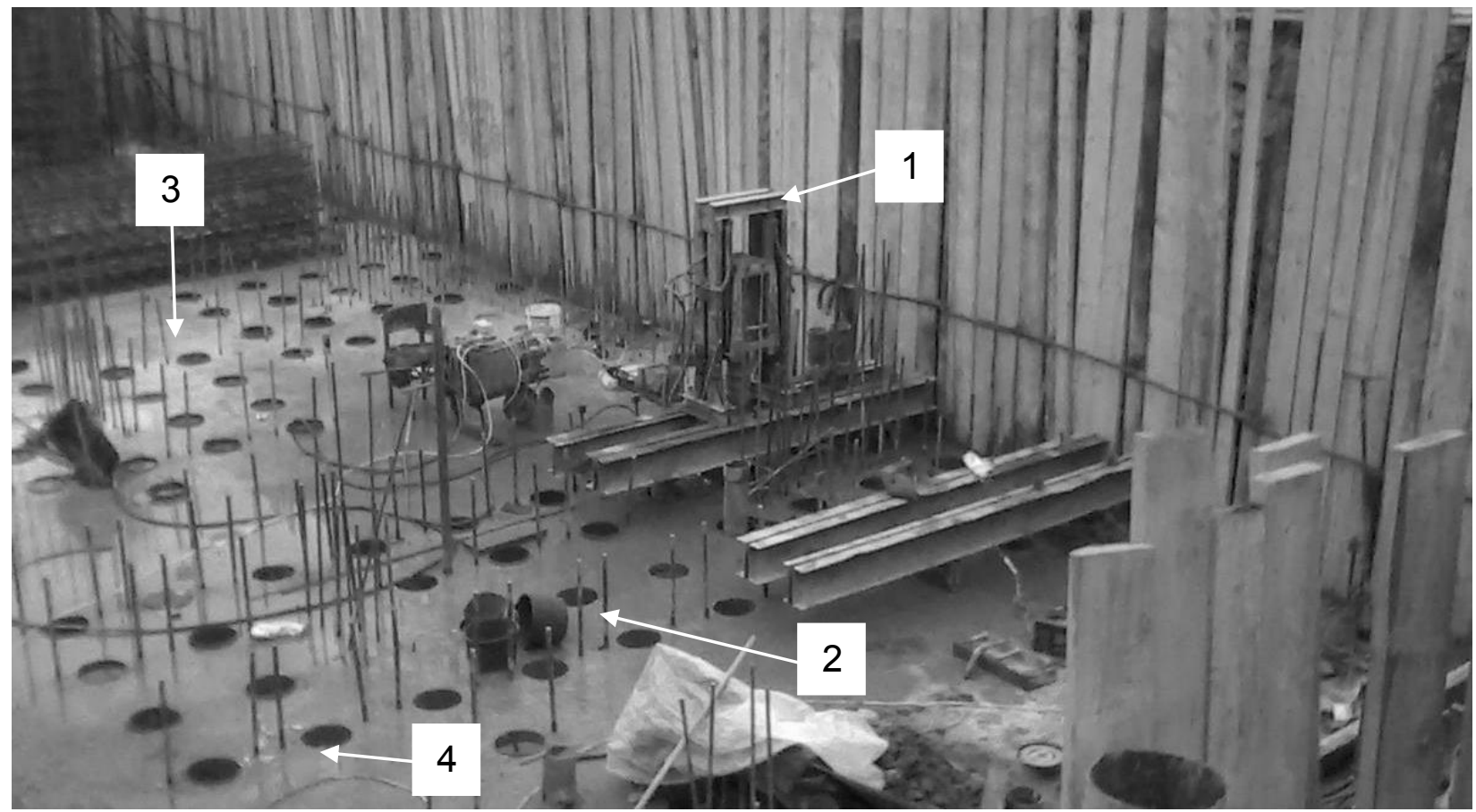

Fig. 5. The process of pressing piles

The pressing unit (1) was attached to the reinforcing anchor rods (2), which were pre-mounted in the reinforced concrete plate (3), so the reactive force from the installation during pressing was perceived by the weight of the plate. After pressing, the piles were connected to the grid plate by welding to the mortgage parts (4). Then the space between the pile and the mortgage part was filled with concrete $\mathrm{C} 20 / 25$.

Engineering-geological section of the site is as follows:

- EGE-1 at a depth of 0.2 to $5.8 \mathrm{~m}$ from the earth's surface lay loose soil; 
- EGE-2 from 5.8 to $6.4 \mathrm{~m}$ there was a sand solid, light, dusty, with dances and traces of iron, brownish-gray (ab IV);

- EGE-3 from 6.4 to $9.4 \mathrm{~m}$ - refractory loam, sticky to the touch, viscous, to a depth, $1.4-1.6 \mathrm{~m}$ silted, then peat and parts with layers of medium peat, sand silted, saturated with water, dark grey (abIII);

- EGE-4 from 9.4 to $10.5 \mathrm{~m}$ - hard clay, carbonate with fine crushed marl (10 - 20\%), gray, bluish-gray (eK2m);

- EGE-5 from 10.5 to $12.1 \mathrm{~m}$ - gravelly soil-gravel weathered, cracked marl with clay aggregate (10\%) low-moisture, gray (eK2m); $(\mathrm{eK} 2 \mathrm{~m})$.

- EGE-6 below $12.1 \mathrm{~m}$ - rocky soil - slightly cracked marl low moisture, softened, gray

Research results. The test results of the pile are presented in the form of graphs of the dependence of «load-sediment» (Fig. 6). Pile loading with static vertical load was completed when the load was reached $\mathrm{F}_{\mathrm{d}}=250 \times 1.2=300 \mathrm{kN}$ when stabilized on two devices of movement of the tested pile №1 - 8.0 mm, piles №2 $-7.5 \mathrm{~mm}$, piles №3 $-6.8 \mathrm{~mm}$.

\section{The relationship between the load on the pile and the average readings of deflectors}

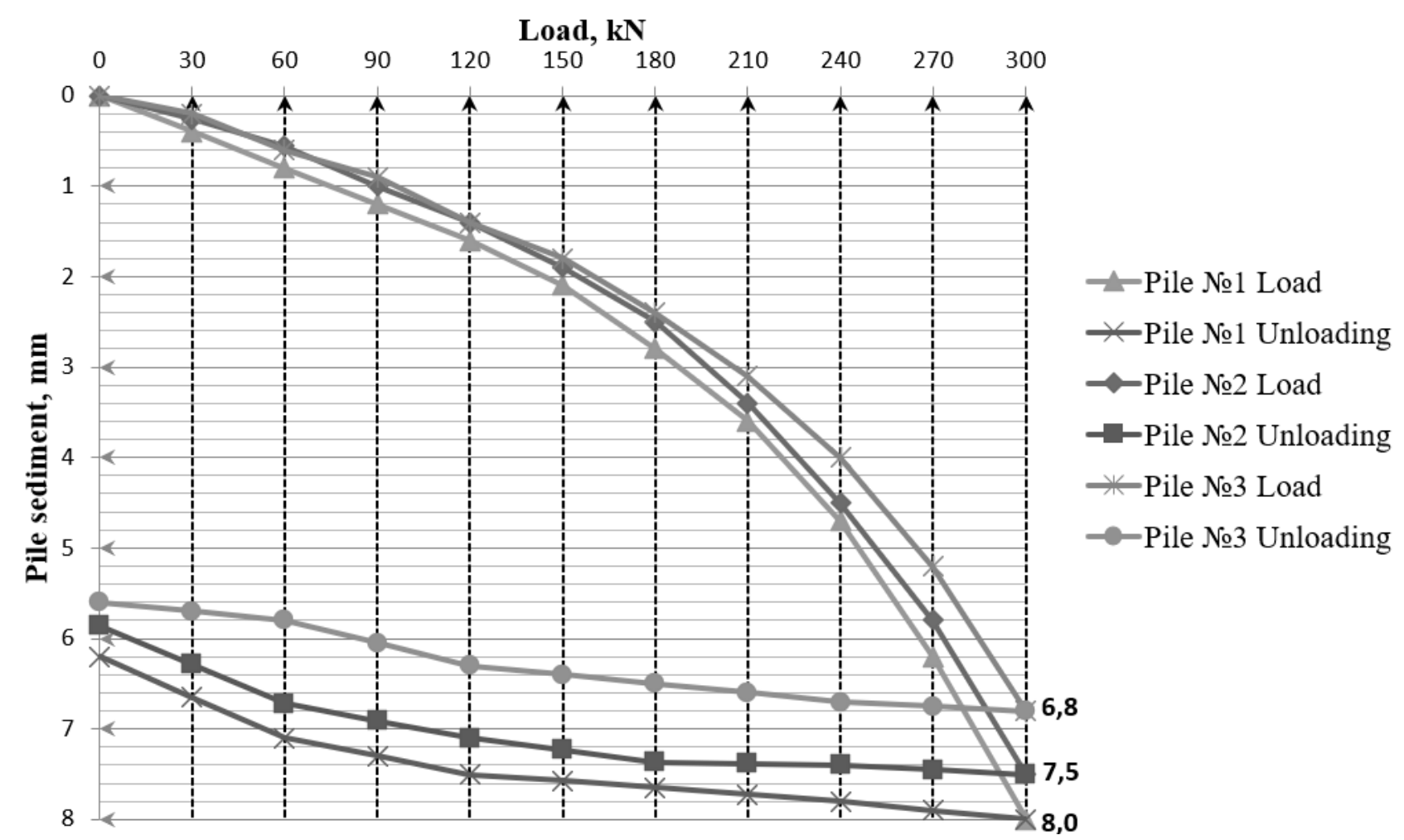

Fig. 6. Graphs of sediment dependence on load

Conclusions. The developed technique of execution of the bases for new construction with use of multi-section pressed piles allowed to cope with the set tasks without additional financial expenses.

All work was performed with small equipment without the use of dynamic loads.

The test results of static loading of multi-section pressed piles showed a subsidence of $7.5 \mathrm{~mm}$ at a load of $300 \mathrm{kN}$, which is less by $37.5 \%$ of the allowable draft of $20 \mathrm{~mm}$.

Basically, such piles are based on compact soils and work as piles, their work in different soil conditions requires further research. 


\title{
References
}

[1] DBN B.1.2-12-2008. Budivnictvo v umovah ushilnenoyi zabudovi. K.: Minregionbud Ukrayiny, 2008.

[2] Micropile Design and Construction. Report No. FHWA-NHI-05-039, United States Department of Transportation, 2005.

[3] O.F. Lebeda, M.V. Kornienko, V.O. Movchan, V.V. Prystupchuk, "Zastosuvannia vdavliuvanykh mikropal pry vlashtuvanni fundamentiv novoho budynku $\mathrm{v}$ umovakh isnuiuchoi zabudovy", Zbirnyk Derzhavnoho pidpryiemstva "Derzhavnyi naukovo-doslidnyi instytut budivelnykh konstruktsii”. Budivelni konstruktsii, vol. 79, pp. 307-312, 2013.

[4] VBN B.2.1-36-2-2002. Pidsylennia fundamentiv budivel ta sporud bahatosektsiinymy vdavliuvanymy paliamy. CJSC "Ukrhydrospetsbudproekt". Kyiv: Ukrmontazhspetsbud, introduced, 2003.

[5] B.V. Morklyanyk Pidsylennia fundamentiv isnuiuchykh budynkiv na slabkykh gruntakh metodom vdavliuvannia pal: dis. ... k-ta tekhn. nauk: 05.23.02, Naukovo-doslidnij institut budivelnih konstrukcij. K.: 2005.

[6] DSTU B V.2.1-1-95. Hrunty. Metody polovykh vyprobuvan paliamy. K.: Derzhkommistobuduvannia Ukrainy, 1996.

\section{ЗАСТОСУВАННЯ БАГАТОСЕКЦЙНИХ ВДАВЛЮВАНИХ ПАЛЬ В КОМПЛЕКСІ 3 ФУНДАМЕНТНОЮ ПЛИТОЮ ПРИ БУДІВНИЦТВІ ГОТЕЛЮ «ТАУРУС»}

\author{
${ }^{1}$ Кунанець Ю.М., аспірант, \\ kunanets.yura@gmail.com, ORCID: 0000-0003-3171-5394 \\ ${ }^{1}$ Демчина Б.Г., д.т.н., професор, \\ ${ }^{1}$ Національний університет «Львівська політехніка» \\ bogdan195809@gmail.com, ORCID: 0000-0002-3498-1519 \\ вул. С. Бандери 12, м. Львів, 79013, Україна
}

Анотація. Під час будівництва в умовах щільної міської забудови інженерам потрібно вирішувати безліч складних завдань. В першу чергу, це пов'язано з ризиком негативного впливу на об'єкти прилеглої забудови і необхідністю додаткових заходів для запобігання такого впливу. Крім того, стиснені умови виконання будівельно-монтажних робіт обмежують використання традиційних технологій, важких машин та механізмів. Проектування правильного i надійного фундаменту в кожному випадку потребує індивідуального підходу. Цей підхід повинен базуватись на всебічному вивченні інженерногеологічних умов.

В статті представлено розроблену методику виконання палевого фундаменту під нову багатоповерхову споруду 3 використанням вдавлюваних багатосекційних трубобетонних мікропаль. Згідно даної методики, всі роботи виконувалися малогабаритним обладнанням без застосування динамічних навантажень. Також була розроблена конструкція плитиростверку, зі спеціальними отворами через які пізніше вдавлювалися багатосекційні палі. Ідея першочергового виготовлення плити-ростверка полягала в тому, щоб ії вагою сприйняти реактивне зусилля від вдавлювальної установки, яка кріпилася до арматурних випусків 3 плити. Після вдавлювання, палі з'єднувалися 3 плитою-ростверком за допомогою приварювання до закладних деталей. Далі простір між палею та закладною деталлю заповнювався бетоном.

Проведено серію випробувань, щоб перевірити несучу здатність паль та їх осадку при розрахунковому навантаженні. Статичне вдавлювання проводилось за допомогою силового стенду який кріпився до арматурних анкерних стержнів, що були попередньо забетоновані в монолітний ростверк. Проведено аналіз ефективності та надійності впроваджених рішень.

150 Bulletin of Odessa State Academy of Civil Engineering and Architecture, 2020, no. 79, page 145-151 
Розроблена методика виконання фундаментів для нового будівництва 3 використанням багатосекційних вдавлюваних паль дозволила справитись 3 поставленими завданнями без додаткових фінансових затрат.

Ключові слова: фундамент, багатосекційні палі, вдавлювання.

\title{
ПРИМЕНЕНИЕ МНОГОСЕКЦИОННЫХ ВДАВЛИВАЕМЫХ СВАЙ В КОМПЛЕКСЕ С ФУНДАМЕНТНОЙ ПЛИТОЙ ПРИ СТРОИТЕЛЬСТВЕ ГОСТИНИЦЫ «ТАУРУС»
}

\author{
${ }^{1}$ Кунанец Ю. М., аспирант, \\ kunanets.yura@gmail.com, ORCID: 0000-0003-3171-5394 \\ ${ }^{1}$ Демчина Б.Г., д.т.н., профессор, \\ ${ }^{1}$ Национальный университет «Львовская политехника» \\ bogdan195809@gmail.com, ORCID: 0000-0002-3498-1519 \\ ул. С. Бандеры 12, г. Львов, 79013, Украина
}

\begin{abstract}
Аннотация. Во время строительства в условиях плотной городской застройки инженерам нужно решать множество сложных задач. В первую очередь, это связано с риском негативного воздействия на объекты прилегающей застройки и необходимостью дополнительных мер по предотвращению такого воздействия. Кроме этого, стесненные условия выполнения строительно-монтажных работ ограничивают использование традиционных технологий, тяжелых машин и механизмов. Проектирование правильного и надежного фундамента в каждом случае требует индивидуального подхода. Этот подход должен базироваться на всестороннем изучении инженерно-геологических условий.

В статье представлена разработанная методика выполнения свайного фундамента под новое многоэтажное сооружение с использованием вдавливаемых многосекционных трубобетонных микросвай. Согласно данной методике, все работы выполнялись малогабаритным оборудованием без применения динамических нагрузок. Также была разработана конструкция плиты-ростверка со специальными отверстиями, через которые позже вдавливались многосекционные сваи. Идея первоочередного изготовления плитыростверка заключалась в том, чтобы еe весом воспринять реактивное усилие от вдавливающей установки, которая крепилась к арматурным выпускам с плиты. После вдавливания, сваи соединялись с плитой-ростверком с помощью приварки к закладным деталям. Далее пространство между сваей и закладной деталью заполнялось бетоном. Проведена серия испытаний, чтобы проверить несущую способность свай и их осадку при расчетной нагрузке. Статическое вдавливание проводилось с помощью силового стенда, который крепился к арматурным анкерным стержням, которые были предварительно забетонированы в монолитный ростверк. Проведен анализ эффективности и надежности внедренных решений. Разработанная методика выполнения фундаментов для нового строительства с использованием многосекционных вдавливаемых свай позволила справиться с поставленными задачами без дополнительных финансовых затрат.
\end{abstract}

Ключевые слова: фундамент, многосекционные сваи, вдавливание.

Стаття надійшла до редакції 29.02.2020

Bulletin of Odessa State Academy of Civil Engineering and Architecture, 2020, no. 79, page 145-151 